\title{
SEXUAL-CHROMATIN AND BREAST TUMORS
}

\section{THE RELATION BETWEEN SEXUAL-CHROMATIN AND HORMONE DEPENDENCY, AND DIFFERENTIATION OF CARCINOMA OF THE BREAST}

\author{
NOBUKATSU SHIMADA,* HIROHARU MATSUDA, \\ and TAKEO AMAAKI \\ Department of Surgery, School of Medicine, Keio University, \\ Tokyo, Japan
}

(Received for publication May 28, 1964)

\section{INTRODUCTION}

Since 1949, when Barr and Bertram(2) made their microscopical discovery of sexual differences in the sexual-chromatin found in the nucleus of ganglion cells of male and female rats, many researchers have been interested in the significance of sexual-chromatin. It was Kimel(21) (U.S.A.) and Hienz(14) (Germany) who first tried to determine the sex of tumors by sexual-chromatin count, and their studies were followed by those of other doctors (Wanke et al $(45,46)$; Coutts et al(7,8); Tavares ${ }^{(41,42)}$; Myers(30); Lehmann et al(27); Graf and Marzoli(12); Regele et $a l^{(34)}$; Rodermund(37); Blümel et ${ }^{\left(l^{(6)}\right)}$. Some of these researchers maintained that the sexual-chromatin count of tumors found in most secondary organs was related to the sex of their hosts; while others stated that those found in secondary sexual organs, namely the breast and prostate, do not correspond to their hosts, possibly due to their hormone dependency.

The purpose of this report is to evaluate the relation (1) of sexual-chromatin count to hormone dependency, and (2) of sexual-chromatin count to the differentiation of malignant tumors of the breast. The former is based upon experiments in which rats were injected with sexual hormones, and the latter is based upon examinations of human breast tissue.

\section{ANIMAL EXPERIMENTS}

Materials and Methods:

Five male and twenty female, mature, castrated Wister rats were separated into five numerically equal groups: Group A (all male) and Groups B, C, D, and

* Chairman of the Department. 
$\mathrm{E}$ (all female). In order to provide a basis for later comparisons, one mammary tissue was resected from each rat prior to castration.

Group A (male rats) was treated daily for one month with $0.3 \mathrm{mg}$ of estradoil dipropionate, I. M. (total, $9 \mathrm{mg}$ ). Group B (female) received no injection of hormones, and Group C (female) was treated exactly as Group A. Group D was treated daily with $1.4 \mathrm{mg}$ of 17 hydroxy-progesterone-17-n-capronate +progesterone (the components of progesterone) in addition to the treatment received by Group C, while Group $\mathrm{E}$ received daily, $3 \mathrm{mg}$ of injections of testosterone heptanoate, I. M. After one month's treatment, the remaining mammary tissue of each rat was resected and the sexual-chromatin was counted microscopically; that is, from 500-1000 nucleus of cells were counted and, on this basis, the percentage of those containing sexual-chomatin was determined.

Results:

The percentage of sexual-chromatin contained in the normal mammary tissue of the male rats ranged between $0-2 \%$, averaging $1 \%$, and of female rats it ranged between 28-32\%, averaging $30 \%$. These percentages are not too dissimilar from the amount of sexual-chromatin found in the human breast tissue (male: less than 3\% and female: 23-30\%) (Table 1).

Table 1.

\begin{tabular}{c|c|c}
\hline Sex of Rats & $\begin{array}{c}\text { Sexual-Chromatin Percentage } \\
\text { of Normal Rats }\end{array}$ & Average \\
\hline \multirow{2}{*}{} & $0-2 \%$ & $1 \%$ \\
우 & $28-32 \%$ & $30 \%$ \\
\hline
\end{tabular}

By group, the percentage of sexual-chromatin varied as follows:

Group A (male): Increased, ranging from $13 \%$ to $22 \%$, averaging $16 \%$.

Group B (female): Decreased, ranging from $12 \%$ to $15 \%$, averaging $14 \%$.

Group $\mathrm{C}$ (female): Almost constant, ranging from $27 \%$ to $33 \%$, averaging $30 \%$, and almost identical to the mammary tissue of normal, female rats and also that of Group D.

Group D (female): See Group C, above.

Group E (female): Decreased, as low as that of Group B above (Table 2).

The above data from Groups $A$ through $E$ suggest that estrogen may be a factor causing sexual-chromatin to increase, while androgen may restrict it; in other words, the level of sexual-chromatin in tissue is dependent upon the level of estrogen. These data also indicate that progesterone does not affect the level of sexual-chromatin. 
Table 2

\begin{tabular}{|c|c|c|c|}
\hline Experiments & Period & $\begin{array}{l}\text { Sexual-Chromatin } \\
\text { percentage }\end{array}$ & Average \\
\hline $\begin{array}{c}\text { 占 Castration }+ \text { Estrogen } \\
\text { Total } 9 \mathrm{mg}\end{array}$ & $1 \mathrm{mo}$. & $13-22 \%$ & $16 \%$ \\
\hline 우 Castration only & $1 \mathrm{mo}$ & $12-15 \%$ & $14 \%$ \\
\hline $\begin{array}{l}\text { 오 Castration }+ \text { Estrogen } \\
\text { Total } 9 \mathrm{mg}\end{array}$ & $1 \mathrm{mo}$ & $27-33 \%$ & $30 \%$ \\
\hline $\begin{array}{l}\text { 오 Castration + Estrogen } \\
\text { Total } 9 \mathrm{mg} \\
+ \text { Progesterone } \\
\text { Total } 42 \mathrm{mg}\end{array}$ & $1 \mathrm{mo}$ & $30-32 \%$ & $31 \%$ \\
\hline $\begin{array}{l}\text { 우 Castration + Androgen } \\
\text { Total } 90 \mathrm{mg}\end{array}$ & $1 \mathrm{mo}$. & $11-14 \%$ & $12 \%$ \\
\hline
\end{tabular}

\section{CLINICAL RESEARCH}

Materials and Methods:

Sexual-chromatin was counted in 136 benign lesions and 110 malignant tumors of the breast. These 246 cases were examined at Keio University Hospital from March, 1960, through February, 1963. The 136 benign cases consisted of 16 cases of intracanalicular fibroadenoma, 4 cases of pericanalicular fibroadenoma, 14 cases of benign cystosarcoma phyllodes, 3 cases of pregnant adenoma, 8 cases of mammary duct ectasia, 2 cases of non-specific purulent mastitis, 1 case of mastitis adolescentium, 70 cases of mammary dysplasia, 6 cases of gynecomastia, and 12 cases of benign intraductal papilloma. The 110 cases of malignant tumors consisted of 65 cases (one male) of carcinoma of the breast, 34 cases of metastasized lymph nodes of the carcinoma of the breast, and 11 cases of relapsed carcinoma of the breast. In addition, the breast tissue (14 normal and 14 atrophic) of 28 normal females was examined by biopsy; these tissues were used to provide a contrast to benign tumors of the breast. Also, to provide a contrast between carcinoma of the breast and the other organs sexual-chromatin was counted for 98 cases of carcinoma of other organs (47 of the stomach, 12 of the rectum, 19 of the esophagus and 20 of the lung).

Clinical Results:

The percentage of sexual-chromatin in normal male breasts was $0 \%$ to $3 \%$, averaging $1 \%$, while that found in normal female breasts was $23 \%$ to $30 \%$, averaging $28 \%$ (Table 3 ). 
Table 3.

Normal Breast Tissue

\begin{tabular}{|c|c|c|}
\hline Sex of Patient & 令 5 cases & 오 14 cases \\
\hline $\begin{array}{l}\text { Sexual-Chromatin } \\
\text { percentage }\end{array}$ & $0-3 \%$ & $23-30 \%$ \\
\hline Average & $1 \%$ & $\begin{array}{r}28 \% \\
r+2.6 \\
\end{array}$ \\
\hline Age & $26-49$ yrs. & $23-47$ yrs. \\
\hline
\end{tabular}

Table 4.

Atrophic Breast Tissue

\begin{tabular}{l|c|c|c|c|c}
\hline & No. of cases & Age & $\begin{array}{c}\text { Sexual-Chromatin } \\
\text { percentage }\end{array}$ & Average & \\
\hline Menopausal & 6 & $52-61$ yrs. & $7-10 \%$ & $9 \%$ & $2-5$ yrs. \\
Post-Menopausal & 8 & $45-71$ yrs. & $1-4 \%$ & $\begin{array}{c}2 \% \\
0+0.9\end{array}$ & $6-23$ yrs. \\
\hline
\end{tabular}

These counts are different significantly from normal breast tissue count beyond 0.003 probability of error

The atrophic breast tissue of menopausal and postmenopausal females showed a lower sexual-chromatin count than the normal breast tissue of menstruating females (Table 4).

Table 5 .

\begin{tabular}{l|c|c|c|c}
\hline \multicolumn{1}{c|}{ Diseases } & $\begin{array}{c}\text { No. of } \\
\text { cases }\end{array}$ & Age & $\begin{array}{c}\text { Sexual-Chromatin } \\
\text { percentage }\end{array}$ & Average \\
\hline Intracanalicular Fibroadenoma & 16 & $18-46$ & $20-26 \%$ & $23 \%$ \\
Pericanalicular Fibroadenoma & 4 & $25-31$ & $21-26 \%$ & $24 \%$ \\
Cystosarcoma Phyllodes & 14 & $13-44$ & $30-35 \%$ & $32 \%$ \\
Pregnant Breast & 3 & $24-31$ & $22-34 \%$ & $30 \%$ \\
Mammary Duct Ectasia & 8 & $20-48$ & $15-33 \%$ & $25 \%$ \\
Non-specific Purulent Mastitis & 2 & 26,42 & $31 \%, 26 \%$ & \\
Mastitis Adolescentium & 1 & 9 & $30 \%$ & \\
\hline
\end{tabular}

Table 6.

Mammary Dysplasia

\begin{tabular}{l|c|c|c}
\hline & No. of cases & Less than 3\% & More than 3\% \\
\hline Sclerosing Adenosis & 30 & 0 & 30 \\
Blunt Duct Adenosis & 8 & 0 & 8 \\
Duct Papillomatosis & 3 & 0 & 3 \\
Fibrous Disease & 9 & 0 & 9 \\
Cystic Disease s̄ Hyperplasia & 17 & 0 & 17 \\
Cystic Disease c Hyperplasia & 3 & 0 & 3 \\
\hline
\end{tabular}


Table 5 shows the sexual-chromatin count of benign tumors of the breast previously mentioned. All of these tumors had a relatively high level of sexualchromatin, especially cystosarcoma phyllodes, pregnant breast, and mastitis adolescentium. Of the 70 cases of mammary dysplasia, all of the tumors had a sexual-chromatin count of more than 3 (Table 6).

As Table 7 indicates, the sexual-chromatin count of fibrous diseases and cystic diseases without epithelial hyperplasia was low $(9-17 \%$ or $18 \%$, averaging $11-12 \%$ ); while for other types of mammary dysplasia, the count was relatively high (sclerosing adenosis, 22-33\%, averaging 24\%; duct papillomatosis, $22-36 \%$,

Table 7.

Mammary Dysplasia

\begin{tabular}{l|r|r|r|r}
\hline & No. of cases & Age & $\begin{array}{c}\text { Sexual-Chromatin } \\
\text { percentage }\end{array}$ & Average \\
\hline Sclerosing Adenosis & 30 & $18-50$ & $22-33 \%$ & $26 \%$ \\
Blunt Duct Adenosis & 8 & $18-40$ & $21-29 \%$ & $24 \%$ \\
Duct Papillomatosis & 3 & $33-47$ & $22-36 \%$ & $27 \%$ \\
Fibrous Disease & 9 & $34-53$ & $9-17 \%$ & $11 \%$ \\
Cystic Disease $\bar{s}$ Hyperplasia & 17 & $33-53$ & $9-18 \%$ & $12 \%$ \\
Cystic Disease c Hyperplasia & 3 & $41-47$ & $21-24 \%$ & $22 \%$ \\
Gynecomastia & 6 & $42-67$ & $4-8 \%$ & $\mathbf{5} \%$ \\
\hline
\end{tabular}

averaging $27 \%$; and cystic disease with epithelial hyperplasia, 21-24\%, averaging $22 \%$ ). Though gynecomastia was low in sexual-chromatin count (4-8\%, averaging $5 \%$ ), it was nevertheless, higher than the normal level.

The sexual-chromatin level of benign intraductal papilloma ranged between $26-30 \%$, averaging $27 \%$, in menstruating patients, but decreased significantly, 8-9\%, in postmenopausal patients. One menopausal patient (within two years) showed a high sexual-chromatin level of $30 \%$, possibly due to a continuing hormone reaction (Table 8 ).

Table 8.

Intraductal Papilloma

\begin{tabular}{l|c|c|c|c|c|}
\hline \multicolumn{1}{c|}{ Menstruation } & No. of cases & Age & $\begin{array}{c}\text { Sexual-Chromatin } \\
\text { percentage }\end{array}$ & Average & \\
\hline Menstruating & 9 & $34-49$ & $26-30 \%$ & $27 \%$ & \\
Menopausal & 1 & 54 & $30 \%$ & 2 yrs. \\
Post-Menopausal & 2 & 61,63 & $9 \%, 8 \%$ & & 10yrs. 13 yrs. \\
\hline
\end{tabular}

Table 9 classifies the cases of carcinoma according to the organs (stomach, rectum, esophagus, lung, and breast), and to the sex of the patients and of the 
Table 9.

Carcinoma of Other Organs

\begin{tabular}{|c|c|c|c|c|c|c|}
\hline Organ & Stomach & Rectum & Esophagus & & Lung & Breast \\
\hline $\begin{array}{l}\text { Sex of Tumor } \\
\text { Sex of Patient }\end{array}$ & $\hat{\delta}$ 우 ? Total & 우우 ? Total & 후오 ? Total & & 오 ? Total & 숭우 ? Total \\
\hline$\hat{o}$ & $\begin{array}{llll}11 & 0 & 13 & 24\end{array}$ & $\begin{array}{llll}4 & 0 & 2 & 6\end{array}$ & $\begin{array}{llll}3 & 0 & 6 & 9\end{array}$ & & $\begin{array}{lll}1 & 4 & 10\end{array}$ & $\begin{array}{llll}1 & 0 & 0 & 1\end{array}$ \\
\hline 오 & $\begin{array}{llll}5 & 2 & 16 & 23\end{array}$ & $\begin{array}{llll}3 & 1 & 2 & 6\end{array}$ & $\begin{array}{llll}2 & 1 & 7 & 10\end{array}$ & 2 & $2 \quad 610$ & $856 \quad 0 \quad 64$ \\
\hline
\end{tabular}

tumors according to sexual-chromatin count. It is apparent from this Table that the sex of tumors is more easily demonstrated in the breast than in other organs.

Among the several types of carcinoma of the breast cited in Table 10 , papillary carcinoma was the highest in sexual-chromatin count $(10-26 \%$, averaging $21 \%$ ), followed by cribriform duct carcinoma $(27 \%$ and $10 \%$, averaging $18 \%$ ). The lowest sexual-chromatin count was found in undifferentiated carcinoma ( $5 \%$ and $1 \%$ ). Some carcinoma of the breast, such as medullary carcinoma, inflammatory carcinoma, lobular carcinoma, intracystic carcinoma, and so-called sweat gland carcinoma, were omitted from Table 10 because the number of cases examined was insufficient for a valid comparison.

Talbe 10.

Over-All Sexual-Chromatin Percentage of Breast Carcinoma

\begin{tabular}{|c|c|c|c|c|}
\hline Histological classification & No. of cases & Age & $\left|\begin{array}{c}\text { Sexual-Chromatin } \\
\text { percentage }\end{array}\right|$ & Average \\
\hline Papillary $\mathrm{Ca}$. & 15 & $31-62$ & $10-26 \%$ & $21 \%$ \\
\hline Duct Ca. & 25 & $32-68$ & $2-18 \%$ & $11 \%$ \\
\hline Mucoid Ca. & 6 & $40-69$ & $4-14 \%$ & $10 \%$ \\
\hline Paget's disease (Duct $\mathrm{Ca}$.) & 4 & $39-56$ & $2-19 \%$ & $7 \%$ \\
\hline Comedo Ca. & 6 & $36-55$ & $1-14 \%$ & $18 \%$ \\
\hline Cribriform Duct Ca. & 2 & 51,71 & $27 \%, 10 \%$ & \\
\hline Medullary Ca. & 1 & 49 & $5 \%$ & \\
\hline Inflammatory Ca. (Duct Ca.) & 1 & 72 & $4 \%$ & \\
\hline Lobular Ca. & 1 & 32 & $11 \%$ & \\
\hline So called Sweat Gland Ca. & 1 & 49 & $5 \%$ & \\
\hline Intracystic $\mathrm{Ca}$. & 1 & 61 & $10 \%$ & \\
\hline Undifferentiated $\mathrm{Ca}$. & 2 & $50,54(\hat{\delta})$ & $5 \%, 1 \%(\hat{b})$ & \\
\hline
\end{tabular}

If patients with carcinoma of the breast were divided into two groups, namely premenopausal (=menstruating) and postmenopausal, the former would show a relatively higher sexual-chromatin percentage (4-27\%, averaging $6 \%$ ) 
Table 11.

Sexual-Chromatin Percentage of Breast Carcinoma

\begin{tabular}{l|c|c|c}
\hline & Menstruating & $\begin{array}{c}\text { Menopausal } \\
6 \text { mo-3 yrs. }\end{array}$ & $\begin{array}{c}\text { Post-Menopausal } \\
4-17 \text { yrs. }\end{array}$ \\
\hline Age & $31-53$ & $50-56$ & $45-72$ \\
Sexual-Chromatin & $4-27 \%$ & $4-23 \%$ & $1-14 \%$ \\
& $\phi 16 \%$ & $\phi 10 \%$ & $\phi 6 \%$ \\
& $\sigma \pm 6.4$ & & $\sigma \pm 4.3$ \\
\hline
\end{tabular}

These counts are significant beyond 0.003 probability of error

than the latter. As far as the sexual-chromatin count of menopausal carcinoma is concerned, it would fall between these two groups (Table 11). It is apparent that the sexual-chromatin count of carcinoma of the breast decreases after menopause; which, in turn, suggests that the hormone dependency of carcinoma of the breast may be indicated by the level of sexual-chromatin present, even though the former does not always correspond to the menstruation stage.

The relation between sexual-chromatin count and the histological classification of tumors, both and the premenopausal and postmenopausal stage, is shown in Tables 12 and 13. From these Tables it is apparent that the sexual-chromatin count of tumors is unrelated to either the premenopausal or postmenopausal stages (example: Papillary Ca., infiltrating type). Also, the sexual-chromatin

Table 12.

Carcinoma of Premenopausal Patients

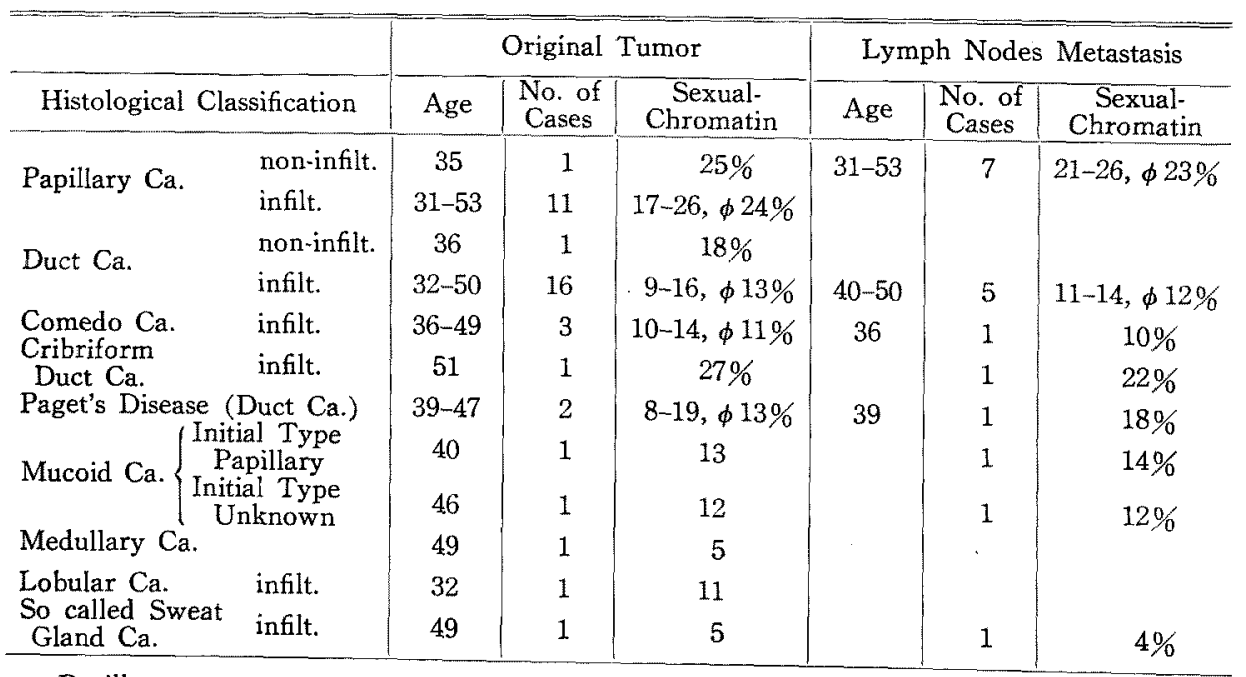

Papillary ca. $\sigma \pm 2.8$, Duct ca. $\sigma \pm 2.1$. These counts are significant beyond 0.003 probability of error 
count of tumors in the same stage varied with the patient (example: Duct Ca., infiltrating type).

Tables 12 and 13 also show the sexual-chromatin count of the original tumors and their metastasized lymph nodes. On the basis of this information, it can be stated that the sexual-chromatin level of metastasized lymph nodes is similar to the sexual-chromatin level of the original tumors, but varies according to the premenopausal and postmenopausal stage.

Table 13.

Carcinoma of Post-menopausal Patients

\begin{tabular}{|c|c|c|c|c|}
\hline \multirow{2}{*}{ Histological Classification } & \multirow{2}{*}{ Age } & \multicolumn{2}{|c|}{ Sexual-Chromatin $(\%)$} & \multirow{2}{*}{ Post-Menopausal } \\
\hline & & Original Tumor & $\begin{array}{l}\text { Lymph Nodes } \\
\text { Metastasis }\end{array}$ & \\
\hline \multirow[t]{3}{*}{ Papillary Ca. infilt. } & 62 & 10 & & 12 yrs. \\
\hline & 60 & $13\} \phi 15 \%$ & & 7 \\
\hline & 56 & 231 & 22 & 3 \\
\hline \multirow{8}{*}{$\begin{array}{ll}\text { Duct Ca. } & \text { non-infilt. } \\
& \text { infilt. }\end{array}$} & 59 & 7 & 8 & 6 \\
\hline & 68 & $2)$ & 2 & 15 \\
\hline & 52 & 20 & 1 & 4 \\
\hline & 49 & 10 & & $\begin{array}{l}\text { Total } \\
2 \text { Hystelectomy }\end{array}$ \\
\hline & 55 & $2\} \phi 5 \%$ & $3 \phi 4 \%$ & 10 \\
\hline & 57 & 3 & & 4 \\
\hline & 52 & 9 & 7 & 1 \\
\hline & 59 & $7)$ & $8)$ & 6 \\
\hline \multirow{3}{*}{$\begin{aligned} \text { Comedo Ca. } & \text { non-infilt. } \\
& \text { infilt. }\end{aligned}$} & 51 & 1 & & 4 \\
\hline & 49 & 4 & 3 & 1 \\
\hline & 55 & $\left.{ }_{2}\right\} 3 \%$ & 2 & 9 \\
\hline Cribriform Duct Ca. & 71 & 10 & & 11 \\
\hline Paget's Disease & 56 & 2 & 1 & 9 \\
\hline (Duct Ca.) & 55 & 2 & 2 & 9 \\
\hline \multirow[t]{4}{*}{ Muciod $\mathrm{Ca}$. } & 56 & 14 & 13 & 6 \\
\hline & 69 & 6 & & 17 \\
\hline & 45 & 4 & & 12 \\
\hline & 49 & 13 & 14 & 7 \\
\hline Inflammatory Ca. (Duct Ca.) & 72 & 4 & 3 & 27 \\
\hline Intracystic $\mathrm{Ca}$ & 61 & 10 & & 8 \\
\hline \multirow[t]{2}{*}{ Undifferentiated $\mathrm{Ca}$. } & 50 & 5 & 4 & $6 \mathrm{mo}$ \\
\hline & $54($ 今 $)$ & 1 & 1 & \\
\hline
\end{tabular}

The percentage of sexual-chromatin in relapsed carcinoma of the breast, except for those resulting from residual carcinoma, was extremely low, all below $5 \%$, for both menopausal and postmenopausal patients (Table 14). 
Table 14.

\begin{tabular}{|c|c|c|c|c|}
\hline Age & $\begin{array}{l}\text { Sexual-Chromatin } \\
\text { Percentage }\end{array}$ & $\mid \begin{array}{c}\text { Histology of } \\
\text { Relapsed Carcinoma }\end{array}$ & Portion of Relapse & $\begin{array}{c}\text { After Radical } \\
\text { Mastectomy }\end{array}$ \\
\hline 54 & 3 & Mucoid Ca. & Lung & 13 yrs. \\
\hline 60 & 1 & " & Local & 8 \\
\hline 37 & 5 & Duct. Ca. & $" \prime$ & 7 \\
\hline 73 & 1 & " & Lung & 9 \\
\hline 51 & 2 & $"$ & Local & 4 \\
\hline 50 & 1 & $" 1$ & $"$ & 3 \\
\hline 56 & 1 & $"$ & " & 5 \\
\hline 51 & 3 & $v$ & Distant Lymph Nodes & 3 \\
\hline 48 & 4 & $" \prime$ & $"$ & 4 \\
\hline 46 & 24 & Papillary Ca. & Homolateral Axillary & Relapse from \\
\hline 36 & 14 & $"$ & Lymph Nodes & Residual Ca. \\
\hline
\end{tabular}

\section{DISCUSSION}

Since 1949 when Barr and Bertram(2) found sexual-chromatin in the nucleus of ganglion cells of rats, many doctors have been interested in the relationship between sex of phenotypically abnormal tissue, and the hormone dependency of carcinoma of the breast. The sexual-chromatin count of normal breast tissue varied from authors to authors, depending upon their criteria of the determination of the count, or the thickness of specimen of their material. Graf(12), for example, investigated the problem and showed that 85 out of 90 cases of mammary displasia showed a sexual-chromatin count of 5-30\%. Although his report did not detail the age or histological classification of cases, these cases of low sexual-chromatin count seemed to be associated with regressive patterns of either fibrous diseases or cystic diseases. Graf(12) also described 9 out of 15 cases of gynecomastia which showed a sexual-chromatin count of $3.5-7.5 \%$, much higher than the count for normal male breast tissue. This count may indicate the hormonal activity of cases of gynecomastia.

Hienz ${ }^{(14)}$ and Kimel(21) tried unsuccessfully to apply sexual-chromatin count to the treatment of carcinoma of the breast; and several other doctors, Lane ${ }^{(25)}$, Berndt(5), Kraus ${ }^{(23)}$, Triska(44), Holieb(16), Wulsin(48), and others, made prognosis of carcinoma of the breast from their histological and statistical aspects.

Lane(25) stated that adenocarcinoma showed the best prognosis, while Berndt(5) and Kraus(23) showed a high five year survival rate for the papillary pattern. Wulsin(48) agreed with others that the prognosis of mucoid carcinoma. and intraductal carcinoma was good; and Triska(44) doubted the successful 
prognosis of carcinoma of the male breast because it lacked an acinus formation necessary for a well differentiated, good prognosis of the disease. Leffall(26), however, objected to both observations, maintaining that the histological pattern was unrelated to the prognosis of the disease.

On the basis of its histological pattern, mucoid carcinoma is a papillary type. Since such well-differentiated carcinoma has a rather high level of sexualchromatin, this may account for its favorable prognosis.

According to Taylor(43), the sexual-chromatin count of female breast tissue, usually $23-30 \%$, significantly decreases following the administration of estrogen, hydrocortisone, or ACTH. This change in the sexual-chromatin count suggests its dependency upon exogenic and endogenic hormones. If this hypothesis should prove medically correct, it would greatly contribute to the treatment of patients with carcinoma of the breast; however, oniy $25 \%$ of relapsed or advanced cases of carcinoma of the breast reacted to the endocrine ablative treatments used by Perlia(31), Jessiman(20), Moore(29) and Graf(12).

Graf(12) stated that out of 170 cases of carcinoma of the breast, 45 (approximately one-fourth) were identified as typically female and 56 as typically male on the basis of their sexual-chromatin count. The remaining 69 cases were intermediary (a stage called "Hiatus" by Blümel(6), Hienz(14), Rodermund(37), Lehmann ${ }^{(27)}$, Tavares ${ }^{(41)}$, and Rivera $\left.{ }^{(35)}\right)$. In his report, Graf(12) indicated that oophorectomy was effective in $25 \%$ of the advanced cases of carcinoma of the breast, and, when combined with therapeutic adrenalectomy, its effectiveness increased to 30-40\%. Related to Graf's report(12), Luft and Olivercroma(28), Ray and Pearson(33), and Jessiman (20), noted in their reports that hypophysectomy was effective in cases of advanced and relapsed carcinoma of the breast. Graf(12) also stated in his report that carcinoma of the breast which did not respond to ablative treatment showed a low sexual-chromatin count.

Kimel(21), on the basis of 91 cases, concluded that high dependency upon estrogen was to be found among carcinoma of the breast with a high sexualchromatin count. He concluded that the sexual-chromatin count was generally low among strong microscopical atypism, although occasionally the sexualchromatin count did exceed $40 \%$.

Some of the additional research results related to this general area were the following: Huggins and $\mathrm{Dao}^{(18)}$ proved the hormonal action of adenocarcinoma of the breast which is well-differentiated. Hienz and Ehler(14) showed that 75 patients in Steinthal's Grade II group, radically mastetomized, showed a high sexual-chromatin percentage, a good prognosis; while, on the contrary, the patients of low sexual-chromatin count had a poor prognosis. Coutts and 
Silver-Inzunza(7) suggested the advantage of sexual-chromatin count as an indicator of endocrine treatment to be used for carcinoma of the breast. Graf(12), supporting this possibility, pointed out that while two-thirds of the patients with carcinoma of the breast with a low sexual-chromatin count died within 5 years after radical mastectomy, even though roentgenic castration and administration of (exogenic) androgen were combined, only one-third of the group with a high sexual-chromatin count died after the same treatment. Wanke ${ }^{(45)}$ and his co-workers published a report which stated that, of 24 patients with carcinoma of the breast with a high sexual-chromatin count, all survived for 5 years after receiving a combination of therapeutic mastectomy, oophorectomy, and testoviron; whereas, approximately one-half of 21 patients with a low sexual-chromatin count died within the same period, although receiving the same treatment. While the preceding information is limited, it would be premature to discuss the hormone dependency of carcinoma of the breast with a sexual-chromatin count of more than $5 \%$ and less than $23 \%$ because it is intermediary, or "Hiatus," as noted above. Regele and others ${ }^{(34)}$ reported that out of 28 cases of carcinoma of the breast only one showed a sexual-chromatin count of "Hiatus," while 20 cases were high in count and seven were low.

According to Blümel(6), 19 cases out of 22 relapses of carcinoma of the breast after surgery showed a low sexual-chromatin count, while the remaining 3 were high in count. On the other hand, 163 out of 330 original carcinoma of the breast examined by him were low in sexual-chromatin count, while 167 were high. He concluded that relapses of carcinoma of the breast are most likely to be found among the original carcinoma of low sexual-chromatin count. The authors of this paper however, believe that the sexual-chromatin count of relapsed carcinoma of the breast may decrease markedly after radical mastectomy as a result of unknown factors, even if the initial tumor showed a high sexualchromatin level. Blümel(6) also found that 4 out of 5 cases of ovarial metastasis of carcinoma of the breast had a high sexual-chromatin count, which he assumed was due to the localized influence of endocrine hormone. On the other hand, experiments by Rivera and others ${ }^{(35)}$ indicate that this may not be the case: esterone, estradiol-17 $\beta$, progesterone, cortisone, corticosterone, and deoxycorticosterone were toxic on the carcinoma of the breast tissue culture taken from mice (cultured with Difco and Hyland Laboratory medium).

Hohmann(15) reported that oophorectomy and androgen were inadequately effective upon 51 cases of carcinoma of the breast, and that the sex ratio of these cases, based upon their sexual-chromatin count, was almost 50:50. Kimel(21), reporting on 91 cases of carcinoma of the breast, showed that positive metastasis 
were high in sexual-chromatin count and were dependent upon estrogen. He classified these 91 cases histologically into four groups: (1) carcinoma simplex, (2) undifferentiated adenocarcinoma, (3) differentiated adenocarcinoma, and (4) intraductal carcinoma. Of these four types, undifferentiated adenocarcinoma had the lowest percentage of sexual-chromatin.

Blümel(6) classified his 330 cases of carcinoma of the breast histologically into three groups: (1) medullary carcinoma, solid carcinoma, and scirrhous carcinoma; (2) solid but partial adenocarcinoma, adenocarcinoma, and mucoid carcinoma; and (3) cribiformed carcinoma, and comedo carcinoma. Although the ratio of high to low sexual-chromatin count in Groups 1 and 2 were almost equal, Group 3's ratio was 13:7. This result indicated that the better differentiated the carcinoma of the breast, the higher the sexual-chromatin count. Blümel(6) warned, however, that the sexual-chromatin count of carcinoma of the breast itself did not properly indicate the histological type of the disease. As the end of his report, he stated that a local relapse of carcinoma of the breast occurred 6 times more frequently in cases with low sexual-chromatin count than those with a high count.

According to Ruef ${ }^{(38)}$, it is important to check the different sexual-chromatin count to prove simultaneous bilateral carcinoma of the breast. Such being the case, the quantitative determination of sexual-chromatin would be important to evaluate the hormone dependency of carcinoma of the breast.

\section{CONCLUSION}

In the animal experiments conducted, estrogen had a favorable influence upon the sexual-chromatin count of castrated male and female rats.

Clinical investigations showed that the normal level of sexual-chromatin in the breast tissue of males ranged from $0-3 \%$, averaging $1 \%$, and females from $23-30 \%$, averaging $28 \%$, decreasing gradually during menopausal and postmenopausal periods. Gynecomastia showed a high sexual-chromatin percentage ( 4 to $8 \%$, averaging $5 \%$ ) which was considered a result of the high estrogen level of the patients.

Except for cystoscarcoma phyllodes, pregnant adenoma, and mastitis adolescentium, for which the percentage was slightly higher, the percentage of sexualchromatin in benign tumors was found to be approximately the same as that of normal, female breast tissue; this was probably due to the high dependency of tumors on estrogen. Especially adenosis and duct papillomatosis showed a high level of sexual-chromatin, and, to the contrary, fibrous diseases and cystic diseases were low in percentage, possibly due to their degenerative changes. The sexual- 
chromatin percentage alterd among premenopausal and postmenopausal patients even with the same disease.

It was also noted that the hormone dependency of breast tumors is not always constant. For example, the fact that carcinoma of the breast has a relatively high percentage level of sexual-chromatin in comparison to carcinoma of other organs, means that the latter are less dependent upon hormones than the former. Postmenopausal carcinoma of the breast showed a lower percentage of sexual-chromatin than did the premenopausal carcinoma. The sexualchromatin percentage level of papillary type carcinoma was the highest among carcinomas of the breast, followed by cribri-formed duct carcinoma; undifferentiated carcinoma was the lowest. Therefore, a high sexual-chromatin percentage level indicates a high differentiation of carcinoma.

Metastasized lymph nodes possessed a percentage level of sexual-chromatin the same as that of the original carcinoma. The percentage of sexual-chromatin found in relapsed carcinoma of the breast was low, possibly due to its minimal hormone dependency.

\section{SUMMRAY}

Sexual-chomatin was microscopically counted following experiments during which rats were injected with sexual hormones and also during the examinations of human breast tissue. It was shown that the level of sexual-chromatin in animal tissue was dependent upon the level of estrogen, and that the level of sexual-chromatin of cilnical cases responded well to the differentiation of carcinoma of the breast.

From these results it is suggested that sexual-chromatin may be a clinical indicator of hormonal application to carcinoma of the breast.

Notice: Our counts are significant beyond 0.003 probability of error.

\section{ACKNOWLEDGEMENTS}

We wish to thank Dr. Leslie R. Bundgaard, Director, University of Maryland, Far East Division, for his advice and assistance in the preparation of this report.

\section{REFERENCES}

1. Barr, M. L.: S. G. O., 99 : 184, 1954.

2. Barr, M. L. and Bertram, E. G.: Nature, Lond., 163: 676, 1949.

3. Barr, M. L., Bertram, E. G., and Lindsay, H. A.: Anat. Rec., 107: 283, 1950.

4. Barr, M. L., and Hobbs, G. E.: Lancet, No. 6822, 1109, 1954.

5. Berndt, H., Friederichs, W. und Schwarz, H.: Dtsch. Gesundh. Wes., 16: 563, 1961.

6. Blümel, G., Turcic, G., Regele, H., und Vagacs, H.: Wien. Klin. Wschr., 75: 41, 
1963.

7. Coutts, W. E. and Silva-Inzunza, E.: Arch. Geschwulstforsch., 12: 385, 1958.

8. Coutts, W. E., Silva-Inzunza, E., and Coutts, W. R.: J. Urol. Med. Chir., 61: 828, 1955.

9. Craig, A. P., Schteingart, D. E., and Shaw, M. W.: J. Clin. Endocr. Metabol., 23: 752, 1963.

10. Daly, D. W., Dossett, J. A., and Jull, J. W.: Brit. J. Surg., 50: 816, 1963.

11. Emery, J. L. and McMillan, M.: J. Path. Bact., 68: 17, 1954.

12. Graf, R. und Marzoli, G. P.: Bruns' Beitr. z. Klin. Chir., 202: 242, 1961.

13. Graham, M. A. and Barr, M. L.: Anat. Rec., 112: 709, 1952.

14. Hienz, H. A. und Ehlers, P. N.: Klin. Wschr., 35 985, 1957.

15. Hohmann, H. G. und Hernández-Richter, J.: Münch. med. Wschr., 29: 1464, 1963.

16. Holieb, A. I. and Farrow, J. H.: S. G. O., 115: 65, 1962.

17. Holzer, F. J. und Marberger, E.: Dtsch. Z. gerichtl, Med., 46: 242, 1957.

18. Huggins, Ch. and Dao, L.-Y. Th.: Cancer Res., 14: 303, 1954.

19. James, J.: Zschr. Zellforsch., 51: 597, 1960.

20. Jessiman, A. G.: Ann. Roy. Coll. Surg. Engl., 24: 213, 1959.

21. Kimel, V. M.: Cancer, 10: 922, 1957.

22. Kosenow, W.: Dtsch. med. Wschr., 83: 971, 1958.

23. Kraus, F. T. and Neubecker, R. D.: Cancer, 15: 444, 1962.

24. Kuhn, E. und Hienz, H. A.: Klin. Wschr., 37: 403, 1959.

25. Lane, N., Goksel, H., Salerno, R. A., and Haagensen, C. D.: Ann. Surg., 153: 483, 1961.

26. Leffall, L. S. D. Jr., White, J. E., and Ewing, J.: S. G. O., 117: 97, 1963.

27. Lehmann, H. Th., Hodges, C. V., and Oyamada, A.: J. Urol. (Baltimore), 81: $172,1959$.

28. Luft, R. und Olivecrona, H.: Schw. med. Wschr., 86: 113, 1956.

29. Moore, K. L., Graham, M. A., and Barr, M. L.: S. G. O., 96: 641, 1953.

30. Myers, L. M.: J. Path. Bact., 78: 29, 1959.

31. Perlia, C. P. and Taylor, S. G. III: Med. Clin. North Am., 47: 159, 1963.

32. Polani, P. E., Hunter, W. F., and Lennox, B.: Lancet, No. 6829, 120, 1954.

33. Ray, P. S. and Pearson, O. H.: Endocrine Aspects of Breast Cancer, Edinburgh, 1958.

34. Regele, H., Vagaes, H., Blümel, G., und Turcic, G.: Wien. Klin. Wschr., 73: $649,1961$.

35. Rivera, E. M., Elias, J. J., Bern, H. A., Napalkov, N. P., and Pitelka, D. R.: J. Nat. Canc. Inst., 31: 479, 1963.

36. Riviere, N.: Cancer, 43: 37, 1957.

37. Rodermund, O. E.: Zschr. Krebsforsch., 61: 259, 1956.

38. Ruef, J. und Ehlers, P. N.: Langenbecks Arch. Klin. Chir., 300: 115, 1962.

39. Schleyer, F.: Schweiz. Z. Path. Bakt., 20: 280, 1957.

40. Selmer-Rennaes: Acta chir. scand., suppl., 266, 1960.

41. Tavares, A. S.: J. Path. Bact., 74: 25, 1957.

41. Tavares, A. S. and Oporto, M. B.: Lancet, No. 6871, 948, 1955.

43. Taylor, A. I.: Lancet, No. 7287, 912, 1963.

44. Triska, H.: Wien. med. Wschr., 112: 335, 1962.

45. Wanke, R., Graf, R. und Marzoli, G. P.: Langenbecks Arch., 295: 96, 1960.

46. Wanke, R. und Kricke, E.: Med. Klin., 13: 534, 1961.

47. Wermer, P.: J. Am. Med. Assoc., 146: 471, 1951.

48. Wulsin, J. and Schreiber, J. T.: Arch. Surg., 85: 791, 1962.

49. Zallena, E., Peracchia, A., und Chiampo, L.: Zschr. Krebsforseh., 64: 83, 1961. 